\title{
Experimental Organism Endocardial Schwannoma
}

National Cancer Institute

\section{Source}

National Cancer Institute. Experimental Organism Endocardial Schwannoma. NCI

Thesaurus. Code C156607.

A malignant schwannoma of the heart arising from subendocardial schwann cells that appear as an expansile spindle cell mass, which may infiltrate the myocardium and protrude into the ventricular lumen. (INHAND) 